\title{
Energy Management System (EMS): The Impact of Natural Ventilation and Shading Control on Thermal Performance of University Building in Winnipeg, Canada
}

\author{
Ali Mohammadzadeh, Miroslava Kavgic, Ali Al-janabi \\ University of Manitoba, Canada
}

\begin{abstract}
High-performance buildings often depend on welldesigned and operated windows and shading. This study aims to optimize the operation of shading devices and use of natural ventilation in a university building with a highly glazed façade, located in extreme continental climate. To meet this aim, a detailed building energy model of the university building was developed in EnergyPlus. After that, the Energy Management System was used to test and develop optimal shading and natural ventilation control strategies that minimize energy consumption while maintaining and potentially improving the indoor environmental quality. The results show that an integrated approach for automatic control of shading is more efficient compared to the individual strategies and can reduce the cooling and heating energy demand by around $20 \%$ and $5.6 \%$, respectively. Moreover, the findings indicate that appropriate ventilation control strategies can reduce the overheating time by 75 hours.
\end{abstract}

\section{Introduction}

The use of shading devices for sun control and natural ventilation for cooling energy reduction are important aspects of many energy-efficient building design strategies. Several studies have shown that effective control of the shading and natural ventilation can reduce energy consumption and satisfy the indoor environmental quality (Foster, 2001; Tzempelikos, 2007; Henze et al., 2004; Moeseke et al., 2007).

Advanced, integrated control strategies have the potential to achieve the largest energy savings while providing high indoor environmental quality. For instance, Tzempelikos and Athienitis (2007) performed an integrated lightingshading control using an advanced window system with motor-controlled shading to investigate the impact of shading on building energy demand and daylight illumination. Similarly, Newsham (1994) used a new version of Hunt's algorithm to model manual control of window shading and electric lighting according to the minimum illuminance level. The results showed that compared to an uncontrolled office, the mean Predicted Percentage of Dissatisfied (PPD) ratio reduced from 22 to $13 \%$, whereas the overheated hours decreased by over 200 hours per year. Yun et al. (2014) studied the effect of lighting and shading control strategies on visual comfort and building energy saving by focusing on a qualitative criterion (glare index) and a quantitative criterion (illuminance), and daylighting. They concluded that the dynamic shading control coupled with lighting could effectively reduce the energy use in the building.

Additionally to shading, natural ventilation has been considered a promising energy efficiency measure for reducing the cooling energy use and providing a healthy and comfortable indoor environment in buildings (Busch, 1992; Allocca et al., 2003; Zhao and Xia, 1998; Finnegan et al., 1984). For instance, Schulze and Eicker (2013) investigated the potential energy saving and thermal comfort performance of naturally ventilated design for three locations, i.e., Stuttgart, Turi, and Istanbul. They concluded that if natural ventilation is appropriately used, the net cooling energy could be saved between 13 and 44 $\mathrm{kWh} / \mathrm{m}^{2}$ per year. In another study, Breesch and Janssens (2010) developed a methodology to estimate the effect of natural ventilation on building thermal performance for a typical office using TRNSYS software. The results showed that the cooling load for a naturally ventilated office building was improved by $8 \mathrm{kWh} / \mathrm{m}^{2}$ per year and the highest thermal comfort was achieved.

Moreover, some studies have shown that the optimal integration of shading systems and natural ventilation could result in a considerable heating and cooling reductions, while improving indoor environmental quality (Moeseke et al., 2007; Sun et al., 2010; Xu et al., 2011). For example, Sun et al. (2010) investigated the integrated control of natural ventilation, shading blinds, and HVAC systems and developed a methodology based on the combination of stochastic dynamic programming and Lagrangian relaxation. The results showed that the integrated control strategies could reduce total energy cost and work better than those traditional individual control methods.

Building energy management system (BEMS) is a sophisticated computer-based method for monitoring and controlling the building's mechanical and electrical equipment that can significantly improve its energy performance. However, the majority of recent developments in BEMS are applied to the active systems, i.e., heating, ventilation, and air-conditioning (HVAC) systems (Doukas et al., 2007) and fewer studies are focused on passive systems such as shading and natural ventilation (Tzempelikos and Athienitis, 2007). Furthermore, optimal control of the shading and natural ventilation depends on many factors such as building design, type, operation, and location. Consequently, 
different buildings will require different solutions and building energy modeling is a useful tool for the development of optimal control strategies. EnergyPlus is an advanced whole-building energy simulation tool that can model in detail building systems and has an in-built Energy Management System (EMS) for the development of various control strategies. EMS is a powerful tool that can be used for the optimal operation of various building systems. For example, Favoino et al. (2015) used the newly introduced actuator in EnergyPlus, "surface construction state actuator," to develop an alternative modeling approach for adaptive glazing, and compared two EMS models against experimental data. The results showed a small discrepancy between the numerical and experimental approaches. In another study, Dutton et al., (2012) implemented a binary stochastic window-opening model in EnergyPlus's EMS feature to evaluate the predictive capacity of new window-opening features in EnergyPlus. The results showed both excellent potential for incorporation of occupant behavior models in EnergyPlus and the need for further development of the tool.

There is a limited number of studies focused on the use of EMS. In particular, there is a lack of research focused on the application of EMS to model integrated control strategies for the shading devices and natural ventilation system to improve the energy performance of the building while maintaining adequate indoor environmental quality in cold climates. This study seeks to extend the existing knowledge related to the optimal operation of shading devices and natural ventilation in the complex university building exposed to extreme weather conditions that vary from $-40{ }^{\circ} \mathrm{C}$ in winter to $+35^{\circ} \mathrm{C}$ in summer. Furthermore, this paper provides new knowledge regarding the implementation of EMS for the development of comprehensive control strategies to improve energy performance and indoor environmental quality. Two different sets of control rules are developed, and their effectiveness and impact on energy consumption and thermal comfort are investigated and analyzed. The first control set evaluated the effect of the external shading management on the heating and cooling energy demands based on indoor temperature and solar radiation levels. The second control set evaluated the effect of natural ventilation on the heating and cooling energy consumptions considering the indoor-outdoor temperatures and room cooling load. To better model realworld conditions, the proposed model also uses several influential parameters such as air-conditioning set point, solar gain, and internal gain (people, lighting and equipment schedules, etc.). The annual unmet Predicted Mean Vote (PMV) hours were used to evaluate the effectiveness of the proposed shading and natural control strategies to improve the indoor thermal comfort quality.

\section{Methodology}

A numerical simulation-based approach was used to evaluate the impacts of shading and natural cooling control strategies on the energy and thermal comfort performance of a studying room located in a university building exposed to an extreme continental climate. The EMS in-built function of EnergyPlus was used to define each set of control scenarios. Two sets of control rules are proposed to regulate solar gains and allow optimal natural cooling. The first set regulated solar gains through the control of the external shading during the day, whereas the natural ventilation management was used to control natural cooling during the operational hours (8:00 to 17:00)

\section{Energy Management System in EnergyPlus}

The built-in EMS function is one of the advanced control methods available in EnergyPlus that allows users to implement customized controls and modeling routines. EMS provides users with a high-level, generalized, supervisory control to override selected aspects of EnergyPlus modeling (U.S. Department of Energy, 2017). The main objective of EMS is to imitate the energy management systems commonly used in real buildings inside the EnergyPlus. Thus, EMS can use a large variety of "sensors" (e.g., indoor temperature and pump energy use) to direct various types of control actions by controlling the "actuators" such as roller shade, or pump valve. All these "sensors" and "actuators" are nodes provided within the EnergyPlus model. For example, similar to the high-level control objects available in EnergyPlus, EMS can turn on and off fans and pumps (AvailabilityManager objects), as well as can change the set point (DemandManager objects) on the system nodes. A simple instructive language called EnergyPlus Runtime Language (Erl) is used to describe the logic of the control algorithms. The program uses Erl to perform the calculation by linking the Erl variables to the EnergyPlus output variables and meters. The EMS then initiates control actions by sending the command to the intended "actuator" and accordingly changes the value of this variable through the Erl program. For further information about the EMS in EnergyPlus, one can refer to Application Guide for EMS provided by EnergyPlus documentation (U.S. Department of Energy, 2017).

\section{Description of thermal zone}

A case study is a south-oriented studying room located on the fourth floor of the newly built LEED Silver Stanley Pauley Engineering Building (SPEB) on the Fort Garry campus at the University of Manitoba in Winnipeg, Canada (Al-janabi et al., 2019). The study room is selected for implementation of the advanced control strategies for two main reasons. First, it has high heating and cooling energy consumptions due to its perimeter location and south orientation. Second, it is a large zone that needs to provide adequate thermal comfort and air quality for a large number of students. Figure 1 depicts the geometry of the SPEB and the selected studying room, whereas Table 1 provides the main characteristics of the selected zone.

Glazing surfaces of the studying room constitute around $95 \%$ of the exterior walls. Thermal transmittances of windows and frames are 0.90 and $0.33 \mathrm{~W} / \mathrm{m}^{2} \mathrm{~K}$, respectively. Each window is equipped with $5 \mathrm{~mm}$ thick exterior shading that has thermal transmittance of 


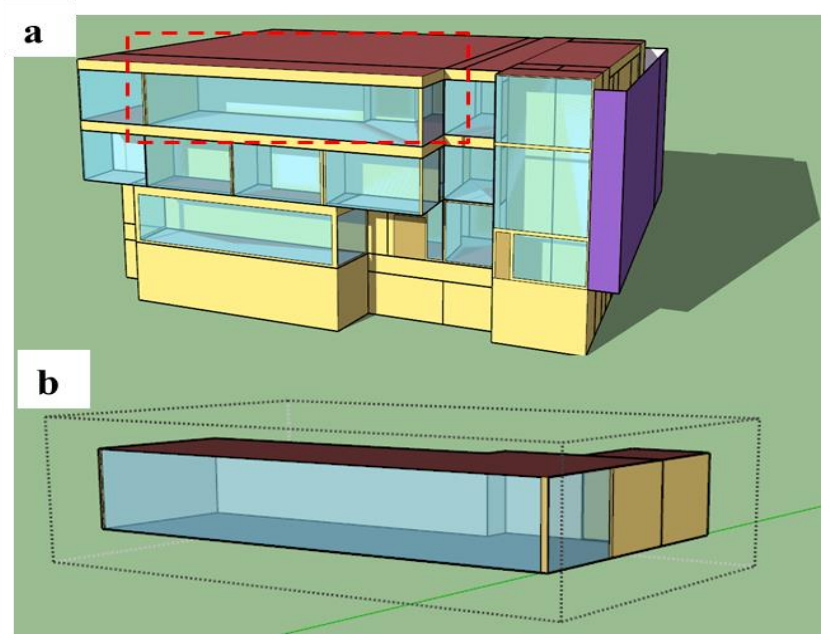

Figure 1: A schematic view of (a) Stanley Pauley Engineering Building (SPEB), (b) studying room.

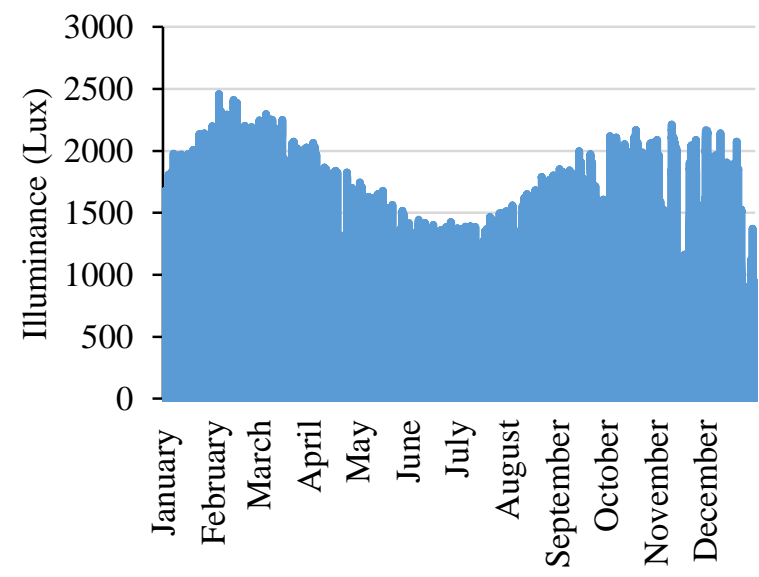

Time (month)

Figure 2: Annual room daylighting when shading with $35 \%$ transmittance is used.

Table 1: Study room characteristics.

\begin{tabular}{lc} 
Floor area $\left(\mathrm{m}^{2}\right)$ & 167.82 \\
Height $(\mathrm{m})$ & 3.50 \\
Total glazing area $\left(\mathrm{m}^{2}\right)$ & 87.85 \\
South glazing $(\mathrm{m} 2)$ & 73.50 \\
East glazing $(\mathrm{m} 2)$ & 14.35 \\
$\begin{array}{l}\text { Total Energy Use }\left(\mathrm{kWh} / \mathrm{m}^{2}\right) \\
\begin{array}{l}\text { Heating Energy Use } \\
\left(\mathrm{kWh} / \mathrm{m}^{2}\right)\end{array}\end{array}$ & 310.23 \\
$\begin{array}{l}\text { Cooling Energy Use } \\
\left(\mathrm{kWh} / \mathrm{m}^{2}\right)\end{array}$ & 246.58 \\
& 63.65 \\
\hline
\end{tabular}

$0.1 \mathrm{~W} / \mathrm{m}^{2} \mathrm{~K}$. It is important to note that the shading and natural ventilation devices have two discrete conditions: (1) retracted (i.e., the window or damper is fully closed), or (2) activated (i.e., the window or damper is fully opened). Internal gains represent a cooling load, and they are divided into three main categories including internal lights $\left(5.76 \mathrm{~W} / \mathrm{m}^{2}\right)$, equipment $\left(7.5 \mathrm{~W} / \mathrm{m}^{2}\right)$, and people $\left(0.515\right.$ person $\left./ \mathrm{m}^{2}\right)$. The studying room is served by the airbased system (composed of variable air volume and fancoil units) and hydronic radiant floor heating and cooling system. Both air and radiant systems are modeled in detail according to the final mechanical drawings, which are used to define a cooling set point $\left(23.9^{\circ} \mathrm{C}\right)$ and set back $\left(26.6^{\circ} \mathrm{C}\right)$ temperatures as well as the HVAC system properties such as air-flow rates, water flow rates, equipment capacities.

\section{First set: shading devices control}

Defined shading control strategies are based on three parameters: (i) the radiation level on the façade, (ii) the mean air temperature, and (iii) the coupled radiation level and indoor temperature. An efficient strategy should minimize the room's energy demand while ensuring adequate vision to the outside and daylight in the room. Tzempelikos and Athienitis (2007) reported that the visual transmittance around $20 \%$ could provide an adequate daylighting for a workplace. Therefore, to balance between the energy savings, occupants' thermal comfort, and daylighting this study assumed $35 \%$ visual transmittance for the external shades. Figure 2 shows the annual illuminance analysis of the study room using EnergyPlus DElight tool (Radiosity technique). It can be seen that approximately $95 \%$ of daily hours the selected shading device provided daylighting of 500 lux, which satisfies the recommendations of National Research Council Canada (Veitch and Newsham, 2000). It is worth to mention that current capabilities of building energy simulation tools to calculate daylight are limited and not as accurate as of the algorithms used in standard daylighting tools. Therefore, the co-simulation between energy-based simulation software and daylighting simulation programs is recommended for future studies.

Three types of management schemes are modeled:

- Only window transmitted radiation level - The screen closes when window transmitted radiation on the vertical south side of the external shading exceeds a specified set point. The set point can vary between 0 $\mathrm{kW}$ and $12 \mathrm{~kW}$, with a $1 \mathrm{~kW}$ step. Figure 3 shows the simulation of shading control strategy in EnergyManagementSystem:Program object for different radiation level.

- Only inside mean air temperature level - Shading closes when internal mean air temperature exceeds a chosen set point. Set point temperature can vary between $22^{\circ} \mathrm{C}$ and $26^{\circ} \mathrm{C}$, with a $0.5^{\circ} \mathrm{C}$ step.

- Window transmitted radiation and inside mean air temperature - The shading is activated when both conditions (i.e., window transmitted radiation level and inside mean air temperature) are met, and disabled if one of the above opening conditions is not satisfied. Table 2 summarizes the applied shading control strategies. 


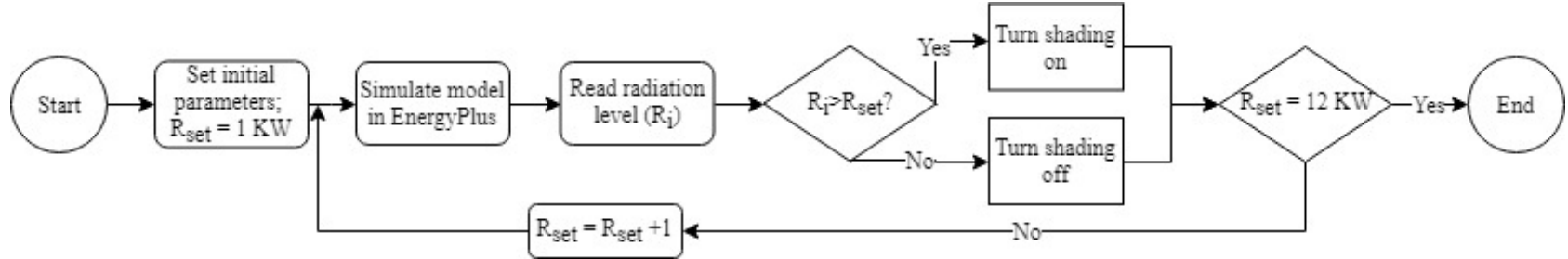

Figure 3: Flowchart of shading device control simulation in EMS based on radiation level set-point.

Table 2: Overview of the applied shading strategies.

\begin{tabular}{l|c|c}
\multicolumn{1}{c|}{ Scenarios } & $\begin{array}{c}\text { Parameter set } \\
\text { points }\end{array}$ & $\begin{array}{c}\text { IF function } \\
\text { defined in } \\
\text { EMS }\end{array}$ \\
\hline $\begin{array}{l}\text { Case 1: activated } \\
\text { based on radiation } \\
\text { level. }\end{array}$ & $\begin{array}{c}\mathrm{R}_{\text {set }}=1-12 \mathrm{~kW} \\
\text { with } 1 \mathrm{~kW} \text { step }\end{array}$ & $R_{i}>R_{\text {set }}$ \\
$\begin{array}{l}\text { Case 2: activated } \\
\text { based on indoor air } \\
\text { temperature. }\end{array}$ & $\begin{array}{c}\mathrm{T}_{\text {set }}=22-26^{\circ} \mathrm{C} \\
\text { with } 0.5^{\circ} \mathrm{C} \text { step }\end{array}$ & $T_{i}>T_{\text {set }}$ \\
$\begin{array}{l}\text { Case 3: activated if } \\
\text { Cases 1-2 are met. }\end{array}$ & $\begin{array}{c}R_{i}>R_{\text {set }} \\
\text { and }\end{array}$ \\
\hline \multicolumn{2}{c}{$\begin{array}{c}T_{i}>T_{\text {set }} \\
\mathrm{R}_{\mathrm{i}}=\text { Radiation level passing through the window, } \mathrm{R}_{\text {set }}=\end{array}$} \\
\multicolumn{2}{c}{ Radiation level set point } \\
\hline
\end{tabular}

\section{Second set: Natural ventilation control}

Natural ventilation is applied through an opening in the plenum, which connects indoor air to the outside and allows the outdoor air to cool down the room according to the active strategy. The control strategies are applied to the EMS based on the four scenarios: (i) mean zone air temperature, (ii) combination of mean air temperature and the difference between internal-external temperatures, (iii) couple measurement of cooling load and internalexternal temperatures, and (iv) combination of the three control strategies. The applied control strategies aim at maximizing thermal comfort and reducing cooling loads by limiting overheating hours and bringing free cool air to the studying room directly from the outside. Four types of management schemes are modeled (see Table 3):

- $\quad$ Only inside mean air temperature level - The damper opens when the mean air temperature reaches the

- higher set point and closes when it falls under the lower set point. The set point varies between $22^{\circ} \mathrm{C}$ to $26^{\circ} \mathrm{C}$, with $0.5^{\circ} \mathrm{C}$ step.

- Inside mean air temperature and internal-external temperatures - Natural cooling starts working when

- the indoor temperature exceeded a predefined set point (i.e., $22^{\circ} \mathrm{C}$ to $26^{\circ} \mathrm{C}$ with $0.5^{\circ} \mathrm{C}$ step), and the outdoor temperature is lower than the indoor temperature.

- Cooling load and internal-external temperatures Damper switches to opens mode if there is a need for cooling in the zone and the outdoor temperature is lower than the indoor temperature.
- Inside mean air temperature, internal-external temperatures, and cooling load - Natural ventilation is used if all three conditions (i.e., indoor temperature, indoor-outdoor temperature, and cooling load) are met and it is turned off if one of above conditions is not satisfied. Figure 4 shows the simulation of natural ventilation control in EnergyManagementSystem:Program object for different indoor-outdoor temperature.

\section{Table 3: Overview of the applied natural ventilation} strategies.

\begin{tabular}{|c|c|c|}
\hline Scenarios & $\begin{array}{l}\text { Parameter } \\
\text { set points }\end{array}$ & $\begin{array}{c}\text { IF function } \\
\text { defined in } \\
\text { EMS } \\
\end{array}$ \\
\hline $\begin{array}{l}\text { Case 1: activated indoor } \\
\text { air temperature. }\end{array}$ & $\begin{array}{l}\mathrm{T}_{\text {set }}=22- \\
26^{\circ} \mathrm{C} \text { with } \\
0.5^{\circ} \mathrm{C} \text { step }\end{array}$ & $T_{i}>T_{\text {set }}$ \\
\hline $\begin{array}{l}\text { Case 2: activated based } \\
\text { on indoor-outdoor } \\
\text { temperature. }\end{array}$ & $\begin{array}{l}\mathrm{T}_{\text {set }}=22- \\
26^{\circ} \mathrm{C} \text { with } \\
0.5^{\circ} \mathrm{C} \text { step }\end{array}$ & $\begin{array}{c}T_{i}>T_{\text {set }} \\
\text { and } \\
T_{i}-T_{0}<0\end{array}$ \\
\hline $\begin{array}{l}\text { Case 3: activated based } \\
\text { on cooling load and } \\
\text { indoor-outdoor } \\
\text { temperature. }\end{array}$ & 0.5 C step & $\begin{array}{c}\text { Cooling }>0 \\
\text { and } \\
T_{i}-T_{o}<0\end{array}$ \\
\hline $\begin{array}{l}\text { Case 4: activated if } \\
\text { Cases 1-3 are met. }\end{array}$ & - & $\begin{array}{c}T_{i}>T_{\text {set }} \\
\text { and } \\
T_{i}-T_{o}<0 \\
\text { and } \\
\text { Cooling }>0\end{array}$ \\
\hline
\end{tabular}

$\mathrm{T}_{\mathrm{i}}=$ Indoor temperature, $\mathrm{T}_{\text {set }}=$ Temperature set point, $\mathrm{T}_{\mathrm{o}}=$ Outdoor temperature

\section{Results and discussion}

To evaluate each set of the developed control strategies regarding energy use and thermal comfort, we analyzed and compared several important parameters such as the cooling and heating energy demand, the mean air temperature, and the Predicted Mean Vote (PMV).

The energy demand is calculated as the heating, and cooling load required to remain the comfort temperature set points in the room, whereas the thermal comfort is measured by a commonly used index PMV. PMV, adopted by the ISO 7730 standard (ISO, 1994), predicts the mean thermal sensation vote of a large group of people on a standard scale ranging from -3 for cold to +3 for hot. The annual unmet PMV hours (i.e., discomfort hours) are calculated when the PMV ratio exceeds the standard, comfortable range (i.e., PMV $>0.5$ or PMV $<-0.5$ ). 


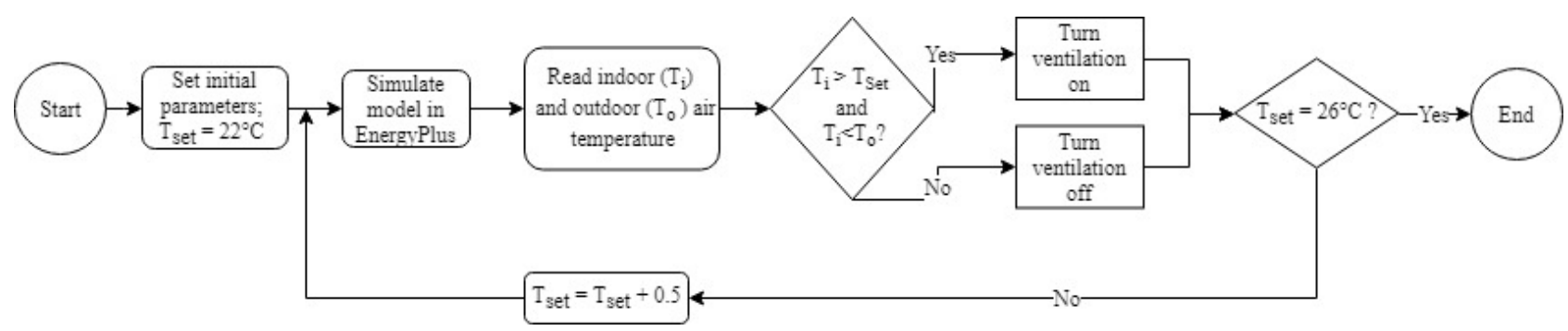

Figure 4: Flowchart of natural ventilation control simulation in EMS based on indoor-outdoor temperature set-point.

\section{Impact of shading control on annual energy use and thermal comfort}

Figure 5 and Table 4 show the annual heating and cooling energy performance of the reference studying room under different shading control strategies. Overall, the results show that the applied shading control strategies can result in significant cooling energy reductions ranging from $21.1 \%\left(13.4 \mathrm{kWh} / \mathrm{m}^{2}\right)$ for the highest set points, respectively to $32 \%\left(20 \mathrm{kWh} / \mathrm{m}^{2}\right)$ for the lowest set points. However, they also indicate that in both modes, the lower set points caused an increase in the heating demand.
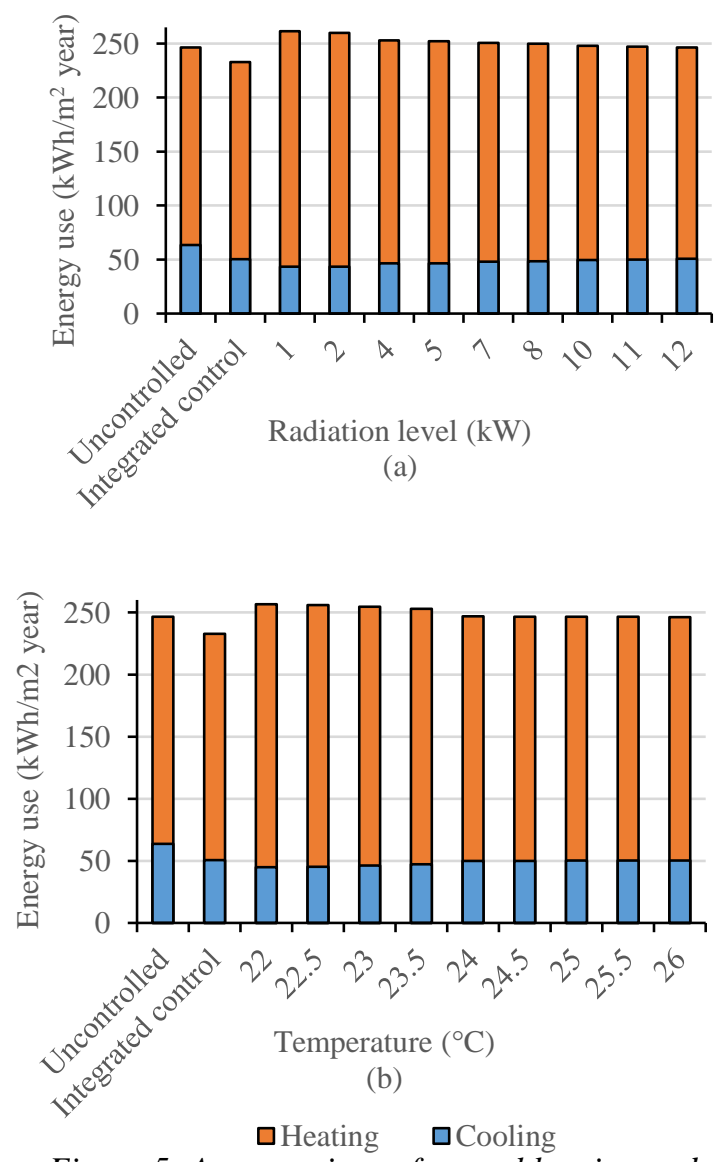

Figure 5: A comparison of annual heating and cooling load for the studying room for different shading control strategies when (a) radiation level and $(b)$ indoor temperature is used.
A possible reason is that the lower set points led to longer use of the shading devices, which eventually increased the heating energy consumption due to reduced solar gains.

For example, the energy demand for heating increased by $5 \%\left(14.8 \mathrm{kWh} / \mathrm{m}^{2}\right)$ and $3 \%\left(9.8 \mathrm{kWh} / \mathrm{m}^{2}\right)$ when the set points for radiation level and indoor temperature were fixed at $1 \mathrm{~kW}$ and $22^{\circ} \mathrm{C}$, respectively. On the other hand, the results demonstrate that the use of higher set points can reduce overheating, without increasing the heating energy use. Therefore, the overall building's energy performance improvement requires analysis of a range of set points to find those that have a positive impact on both heating and cooling demand. Figure 5 also shows that compared to the individual strategies the integrated control strategies offer larger energy saving potentials for both heating and cooling loads. For example, the heating and cooling energy consumptions were reduced by $5.6 \%$ $\left(13.8 \mathrm{kWh} / \mathrm{m}^{2}\right)$ and $20.7 \%\left(13.2 \mathrm{kWh} / \mathrm{m}^{2}\right)$, respectively. Consequently, the integrated shading controls based on both radiation level and indoor temperature have the potential to improve the overall building's energy performance.

As already mentioned, PMV was used to assess the level of thermal performance resulting from the application of different shading control strategies. It is important to note that it is difficult to evaluate the thermal comfort accurately using PMV, due to the uncertainty regarding subjective parameters, such as clothing thermal insulation $\left(\mathrm{I}_{\mathrm{cl}}\right)$, and metabolic rate $(\mathrm{M})$. In this study, $\mathrm{I}_{\mathrm{cl}}$ varies between 0.5 and 0.9 based on the daily outdoor temperature, and $\mathrm{M}$ is equal to 1 for a medium office activity (ASHRAE 55-2010). The hourly PMV values are calculated for the occupied hours (i.e., 8:00 to 17:00). Figure 6 shows the comparison of the annual unmet PMV hours (i.e., discomfort hours) and activated hours (i.e., the number of hours that shading is operational) for different shading control strategies under various set points. It is evident that both radiation and temperature control strategies have a similar impact on room thermal comfort.

It can be seen that an increase in the radiation level set point increased the number of discomfort hours. For instance, an increase of the radiation levels above $3 \mathrm{~kW}$ increased the number of discomfort hours from 25 hours for $4 \mathrm{~kW}$ to 70 hours for $12 \mathrm{~kW}$. Similarly, an increase in the temperature set point from $22{ }^{\circ} \mathrm{C}$ to $26^{\circ} \mathrm{C}$ resulted in 
a $55 \%$ increase of the discomfort hours and a drop of $96 \%$ of the activated mode hours.

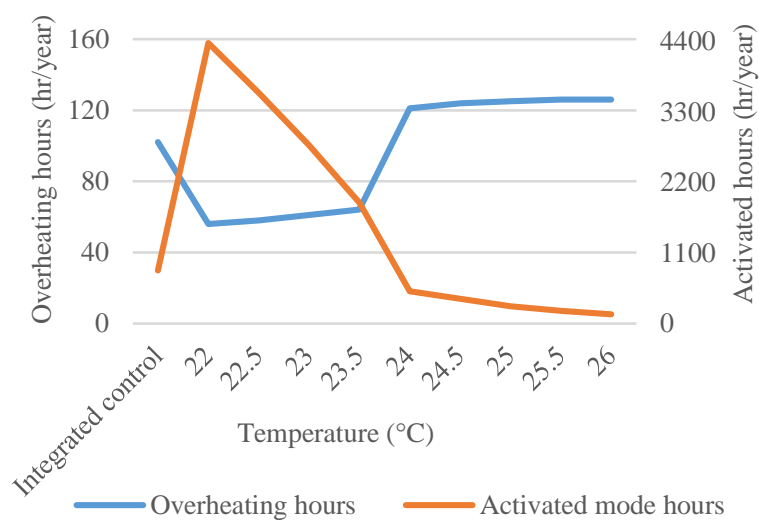

Figure 6: Overheating and activated mode hours in a studying room for various radiation set point.

Table 4: Annual heating and cooling energy demand and saving for the studying room under different shading control strategies.

\begin{tabular}{cccc}
\hline Strategy & set points & $\begin{array}{c}\text { Heating } \\
\left(\mathbf{k W h} / \mathbf{m}^{2} \text { year }\right) \\
(\mathbf{S a v i n g} \%)\end{array}$ & $\begin{array}{c}\text { Cooling } \\
\left(\mathbf{k W h} / \mathbf{m}^{2} \text { year }\right) \\
(\mathbf{S a v i n g} \%)\end{array}$ \\
\hline No control & - & $246.6(-)$ & $63.6(-)$ \\
\hline Shading & & & \\
Case 1 & $1 \mathrm{~kW}$ & $261.4(-5.7)$ & $43.3(32.0)$ \\
& $3 \mathrm{~kW}$ & $256.5(-3.8)$ & $45.1(29.2)$ \\
& $7 \mathrm{~kW}$ & $250.8(-1.7)$ & $47.9(24.8)$ \\
& $9 \mathrm{~kW}$ & $248.9(-0.9)$ & $48.9(23.1)$ \\
& $11 \mathrm{~kW}$ & $247.2(-0.2)$ & $50.1(21.4)$ \\
Case 2 & $22^{\circ} \mathrm{C}$ & $256.7(-3.9)$ & $44.8(29.6)$ \\
& $23^{\circ} \mathrm{C}$ & $254.5(-3.1)$ & $46.2(27.4)$ \\
& $24^{\circ} \mathrm{C}$ & $246.9(-0.1)$ & $49.9(21.6)$ \\
& $25^{\circ} \mathrm{C}$ & $246.4(0.1)$ & $50.1(21.3)$ \\
& $26^{\circ} \mathrm{C}$ & $246.3(0.1)$ & $50.2(21.1)$ \\
Case 3 & - & $232.7(5.6)$ & $50.4(20.7)$ \\
\hline
\end{tabular}

\section{Impact of natural ventilation control on annual energy use and thermal comfort}

Figure 7 illustrates whereas Table 5 summarizes the impact of the various natural ventilation strategies on the annual heating and cooling energy demands. The bars shown in cases 1 and 2 correspond to the heating and cooling energy use when natural ventilation is regulated only by indoor air temperature (left bar) and by indooroutdoor air temperatures (right bar). Whereas, cases 3 and 4 relate to the heating and cooling load when natural ventilation is controlled based on cooling load and integrated control design.

The overall results indicate that the use of natural ventilation can result in significant cooling energy reductions compared to the uncontrolled mode. Thus, the cooling loads were reduced by around $29 \%$ and $30 \%$ for the first and second case, respectively. However, compared to the lower set points, the modes with higher set points resulted in lower cooling saving. This similarity with the shading control strategies can be explained by the increase in the number of ventilation operation hours with a reduction in temperature set points. For example, the cooling savings increased from $12 \%$ to $28 \%$ when the temperature set point decreased from $26^{\circ} \mathrm{C}$ to $22.5^{\circ} \mathrm{C}$. Figure 7 also shows that incorporation of the outdoor temperature into the first case does not have a significant impact on the cooling or heating savings in the cold region, except for the set point $23.5^{\circ} \mathrm{C}$ when the cooling load improved by $14 \%$ (from 55.7 to $47.83 \mathrm{kWh} / \mathrm{m}^{2}$ year).

The results also demonstrate that the incorporation of natural cooling can increase the heating energy load. For example, for the first and second case with the lower set points, the heating load increased by $3.9 \%$ and $3.8 \%$, respectively, whereas for the third and fourth case the heating load increased by $2 \%$ and $1.5 \%$, respectively. Berkeley Lab and EnergyPlus development team are currently working on understanding the cause of the increase in the heating load when running a scenario with natural ventilation. For a possible reason, they reported that whenever the fans come on heating also activates and although program checks the zone temperature and turns off the heating if not needed, over the entire year, short but frequent heating use adds up in terms of a heating load (U.S. Department of Energy, 2017).

It is also evident that an increase in the temperature set points results in an increase in the overheating hours and a decrease in the number of activated hours. For instance, the temperature set point increase from $22^{\circ} \mathrm{C}$ to $26^{\circ} \mathrm{C}$ led to an increase in the overheating hours from 65 to 120 hours. Moreover, it is shown that the second case (i.e., based on both internal and outside temperature) limiting the flow rate is found to have no major impact on comfort conditions.

Table 5: Annual heating and cooling energy demand and saving for the studying room under different natural ventilation control strategies.

\begin{tabular}{cccc}
\hline Strategy & set points & $\begin{array}{c}\text { Heating } \\
\left(\mathbf{k W h} / \mathbf{m}^{2} \text { year) }\right. \\
\text { (Saving \%) }\end{array}$ & $\begin{array}{c}\text { Cooling } \\
\left(\mathbf{k W h} / \mathbf{m}^{2} \text { year) }\right. \\
\text { (Saving \%) }\end{array}$ \\
\hline No control & - & $246.6(-)$ & $63.6(-)$ \\
\hline Ventilation & & & \\
Case 1 & $22^{\circ} \mathrm{C}$ & $256.5(-3.9)$ & $45.4(28.7)$ \\
& $23^{\circ} \mathrm{C}$ & $259.1(-4.8)$ & $45.4(28.7)$ \\
& $24^{\circ} \mathrm{C}$ & $261.2(-5.6)$ & $48.2(24.2)$ \\
& $25^{\circ} \mathrm{C}$ & $261.2(-5.6)$ & $55.7(-5.6)$ \\
& $26^{\circ} \mathrm{C}$ & $261.2(-5.6)$ & $55.8(12.4)$ \\
& $22^{\circ} \mathrm{C}$ & $256.7(-4.0)$ & $44.8(29.5)$ \\
& $23^{\circ} \mathrm{C}$ & $257.4(-4.2)$ & $45.5(28.5)$ \\
& $24^{\circ} \mathrm{C}$ & $261.2(-5.6)$ & $55.7(12.6)$ \\
& $25^{\circ} \mathrm{C}$ & $261.2(-5.6)$ & $55.7(12.5)$ \\
& $26^{\circ} \mathrm{C}$ & $261.2(-5.6)$ & $55.7(12.5)$ \\
Case 2 & - & $259.2(-4.9)$ & $49.3(22.5)$ \\
& & $259.3(-4.9)$ & $49.4(22.4)$ \\
\hline
\end{tabular}



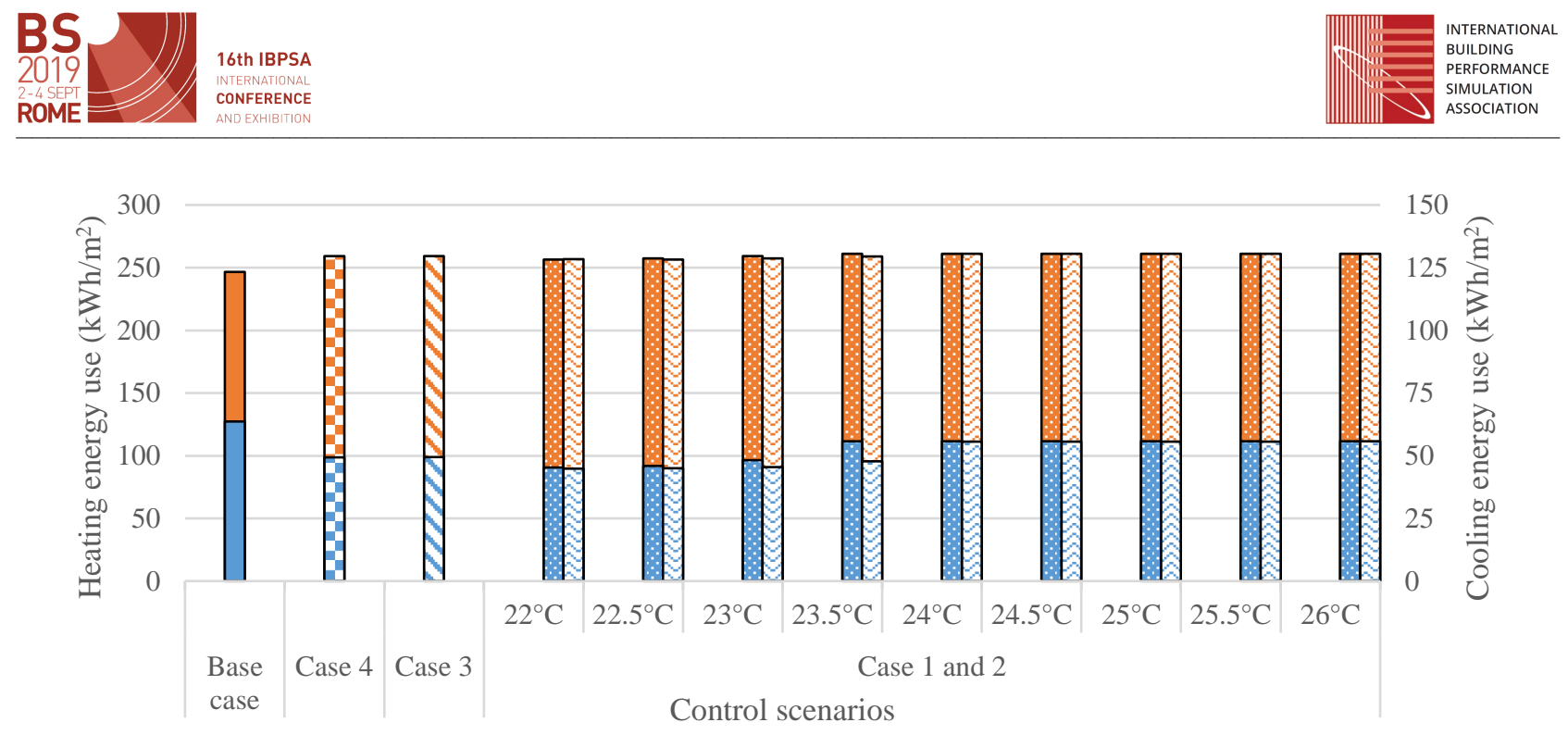
$\square$ Heating - Base case $\boldsymbol{\square}$ Heating - Case 4
-Cooling - Base case घCooling - Case 4
घHeating - Case 3
$\square$ Cooling - Case 3
$\square$ Heating - Case 1
曰Heating - Case 2
๑Cooling - Case 1
๑Cooling - Case 2

Figure 7: A comparison of annual heating and cooling load in a studying room for different natural ventilation control strategies.

To enable a closer insight into the thermal comfort of the studying room, a more detailed analysis of average indoor temperature and PMV ratio is carried out about the integrated control strategy. Figure 8 shows a weekly comparison of average indoor temperature and PMV ratio when integrated natural ventilation control is used. It can be seen that the indoor thermal comfort can be improved and in particular between 10:00 and 15:00 when the solar gains are the largest. Compared to the reference mode, the natural ventilation management resulted in considerable indoor thermal comfort improvements during operational hours.

\section{Conclusion}

High-performance buildings often depend on welldesigned and operated windows and shading. However, optimal control of the shading and natural ventilation depends on many factors such as building design, type, operation, and location. As a result, different buildings will require different solutions. This study seeks to extend the existing knowledge related to the optimal operation of shading devices and natural ventilation in highly glazed institutional buildings exposed to extreme weather conditions. Furthermore, it provides new knowledge regarding the use of EMS for the implementation of advanced shading and natural ventilation control strategies.

Two different sets of the control rules for shading and natural ventilation are developed, and their effectiveness and impact on the energy consumption and thermal comfort of the studying room are evaluated.

The first set of control rules is applied to the shading device considering the indoor temperature and solar radiation levels. The second set of the control rules is applied to the natural ventilation considering the indooroutdoor temperatures and room cooling loads. The overall results suggest that in climates such as Winnipeg where temperatures range from $-40{ }^{\circ} \mathrm{C}$ in winter to $+35{ }^{\circ} \mathrm{C}$ in summer, some shading and natural ventilation strategies can have a positive impact on the cooling energy demand but negative on heating energy demand. For instance, although the lower set points for radiation and temperature levels used for the shading controls reduced cooling energy demand by more than $30 \%$, they caused an increase in the heating demand. The likely reason for the increase in the heating energy demand is the reduction of passive solar heating during the winter months caused by the longer use of the shading devices. On the other hand, the integrated control strategies, which consider both solar radiation and indoor temperature, had a positive impact on the overall energy consumption and reduced heating and cooling demand of the studying room by $5.6 \%\left(13.8 \mathrm{kWh} / \mathrm{m}^{2}\right)$ and $20.7 \%\left(13.2 \mathrm{kWh} / \mathrm{m}^{2}\right)$, respectively.

The results also show that control strategies for the implementation of natural ventilation have great potential to reduce cooling demand while improving indoor thermal comfort in climates such as Winnipeg. For instance, the appropriate ventilation control strategies can reduce the cooling demand by $10 \%$ to $30 \%$ and the overheating time by 75 hours. We, however, noticed a small increase, ranging from $1.5 \%$ to $3.9 \%$, in heating demand when running natural ventilation scenarios. Analysis of the high-resolution results (e.g., $15 \mathrm{~min}$ ) confirms the preliminary findings of the Berkeley Lab that the use of fans for natural ventilation activates the heating system. Although the program checks the zone temperature and turns off the heating if not needed, over the entire year, short but frequent heating use adds up in terms of a heating load (U.S. Department of Energy, 2017).

Findings from this study suggest that designers should focus more on the development of the optimal control systems for shadings and natural ventilation systems that can improve the overall energy performance and indoor environmental quality of buildings. For the best results, this type of detailed integrated analysis should be carried out during the early stage of the design when critical 
decisions will have a major impact on the energy performance during the use phase of the building. Our. future work will include the development of the control strategies that integrate shading and natural ventilation.

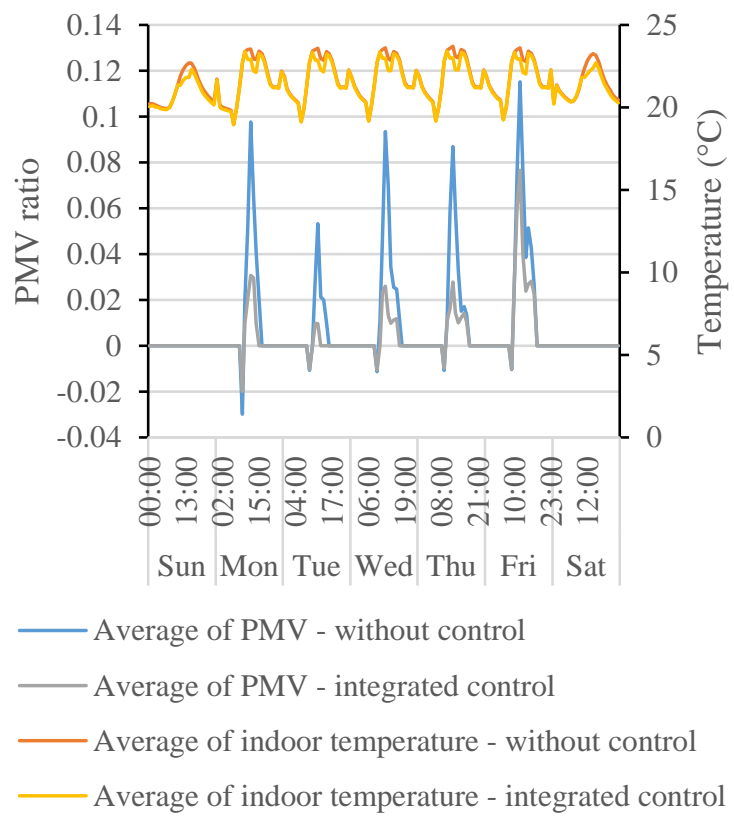

Figure 8: A comparison of weekly average indoor temperature and PMV index between integrated ventilation control and uncontrolled models.

\section{References}

Al-janabi, A, Kavgic, M, Mohammadzadeh, A, Azzouz, A. (2019). "Comparison of EnergyPlus and IES to model a complex university building using three scenarios: Free-floating, Ideal air load system, and Detailed." Journal of Building Engineering (Journal of Building Engineering) 262-280.

Alloccaa, C, Chen, Q, Glicksman, L. (2003). "Design analysis of single-sided natural ventilation." Energy and Buildings 785-795.

ASHRAE Standard 55-2010. n.d. "Thermal Environment Conditions for Human Occupancy, American Society of Heating, Refrigerating and AirConditioning Engineers, Inc."

Breesch, H, Janssens, A. (2010). "Performance evaluation of passive cooling in office buildings based." Solar Energy 1453-1467.

Busch, J. (1992). "A tale of two populations: thermal comfort in air-conditioned and naturally ventilated offices in Thailand." Energy and Buildings 235-249.

Doukas, H, Patlitzianas, K, Iatropoulos, K, Psarras, J. (2007). "Intelligent building energy management system using rule sets Haris." Building and Environment 3562-3569.

Dutton, S, Zhang, H, Zhai, Y, Arens, E, Smires, Y, Brunswick, S, Konis, K, Haves, P. (2012). "Application of a stochastic window use model in EnergyPlus.” Proceedings of SimBuild 63-70
Fanger, P. (1984). Moderate Thermal Environments Determination of the PMV and PPD Indices and Specification of the Conditions for Thermal Comfort. ISO 7730

Fanger, P. (1970). "Thermal comfort. Analysis and applications in environmental engineering." Thermal comfort. Analysis and applications in environmental engineering.

Favoino, F, Cascone, Y, Bianco, L, Goia, F, Zinzi, M, Overend, M, Serra, V, and Perino, M. (2015). "Simulating switchable glazing with energyplus: an empirical validation and calibration of a thermotropic glazing model". Proceedings of building simulation.

Finnegan, M, Pickering, C, and Burge, P. (1984). "The sick building syndrome: prevalence studies." $\mathrm{Br} \mathrm{Med}$ $J$ (Clin Res Ed) 1573-1575.

Foster, M, Oreszczyn, T. (2001). "Occupants control of passive systems: the use of Venetian blinds." Building and Environment 149-155.

Henze, G, Felsmann, C, Knabe, G. (2004). "Evaluation of optimal control for active and passive building thermal storage." International Journal of Thermal Sciences 173-183.

ISO. (1994). "International standard 7730: Moderate thermal environment - Determination of the PMV and PPD indices and specification of the conditions of thermal comfort .'

Moeseke, G, Bruyere, I, Herde, A. (2007). "Impact of control rules on the efficiency of shading devices and free cooling for office buildings." Building and Environment 784-793.

Newsham, G.R. (1994). "Manual Control of Window Blinds and Electric Lighting: Implications for Comfort and Energy Consumption." Indoor and built environment 135-144.

Schulze, T, Eicker, U. (2013). "Controlled natural ventilation for energy efficient buildings." Energy and Buildings 221-232.

Sun, B, Luh, P, Jia, Q, Jiang, Z, Wang, F, and Song, C (2010). "An Integrated Control of Shading Blinds, Natural Ventilation, and HVAC Systems for Energy Saving and Human Comfort." 6th annual IEEE Conference on Automation Science and Engineering. Toronto.

Tzempelikos, A, Athienitis, A. (2007). "The impact of shading design and control on building cooling and lighting demand." Solar Energy 369-382.

U.S. Department of Energy. (2017). Application Guide for EMS. EnergyPlus.

U.S. Department of Energy. (2017). Input Output Reference. The Encyclopedic Reference to EnergyPlus Input and Output. EnergyPlus.

U.S. Department of Energy. (2017). Natural Ventilation - Heating load increases. September. 
https://windows.lbl.gov/tools/knowledgebase/articles/natural-ventilation.

Veitch, J.A., and Newsham, G.R.. (2000). Preferred luminous conditions in open-plan offices: research and practice recommendations. 199-212: National Research Council Canada (NRCC).

Xu, X, Jia, Q, Chen, X, Guan, X, Jiang, Z. (2011). "Analysis of Energy Saving Potential using Shadings and Natural." 30th Chinese Control Conference. China.
Yun, G, Yoon, K, Kim, K. (2014). "The influence of shading control strategies on the visual comfort and energy demand of office buildings." Energy and Buildings $\mathrm{j}$ 70-85.

Zhao, R., and Xia, Y. (1998). "Effective non-isothermal and intermittent air movement on human thermal responses." Proc. of Roomvent. 